\title{
The United States and Canada: State Policy and Strategic Perspectives on Capital in Central America
}

\author{
James Petras and Morris Morley
}

\section{Introduction}

Central America has been directly affected by the crisis of US hegemony on a world scale and the global economic crisis. The latter has exacerbated many existing regional problems; for example, rocketing interest rates have had serious impacts on debt payments, and the decline of markets for the area's raw materials has coincided with a rise in protectionist policies in the industrialised West. The result has been to limit the export of industrial goods from Central America on the one hand and to contract investment surpluses, especially in open economies, on the other. Externally, Central America has been defined by the Reagan administration as an arena for recouping US global supremacy through military confrontation and victory. This, in turn, is used to justify the rise in military expenditures and the interventionist behaviour which characterises Washington's New Cold War policy. This article presents a comparative analysis of the United States and Canadian economic interests and state policies with respect to Central America. For the purposes of this article, Central America refers to El Salvador, Honduras, Guatemala and Nicaragua.

\section{United States and Central America: the economic dimension}

Although the internal politics of the Central American region have been fraught with instability, diverse sectors of US capital have had no difficulty adjusting their interests over time. While the types, scope and direction of capital flows have varied - beginning with direct investment in agriculture and mining, followed by manufacturing, financial loan capital, state and international bank capital - there has been no significant rupture or division among them regarding US policy, or their relations with dictatorial regimes.

During the post-World War I period, the United States displaced Britain as the dominant economic power in Central America. Between 1919 and 1929,
American investment more than doubled to $\$ 251 \mathrm{mn}$ and was located in every important sector of the Central American economies including railroads, banking, public utilities, industries, mining, and banana and rubber plantations. From the Great Depression to the Alliance for Progress, the pattern of metropolitan capital flows served to consolidate and deepen the monoculture economy and dependence on agricultural export. Between 1950 and 1959, for instance, almost $\$ 100 \mathrm{mn}$ in new US investments went into the region, mostly into public utilities, minerals, agro-exports, and the highly profitable food and raw material producing sectors [LaFeber 1983:60-2, 1278]. While the tripling of US direct investments between 1960 and 1980 was paralleled by an increasing concentration of new capital in manufacturing activity (from $\$ 12 \mathrm{mn}$ to $\$ 147 \mathrm{mn}$ ), the diminished proportion of new investments in agriculture and mining enterprise did not imply the erosion of the monoculture export-oriented economy [US Department of Commerce 1981:31-2, 1982:1-27, 1983:23-4]. Central America still remained a cluster of largely agricultural based economies dominated by American multinationals.

Financial capital, and more particularly the largest US multinational banks, such as the Bank of America, Citicorp, and Chase Manhattan, began to play an increasingly important role in Central America during the 1970s as governments sought to cope with the twin problems of spiralling oil import costs and declining export markets. Between 1970 and 1981 total gross inflows of medium and long-term loans increased from $\$ 118 \mathrm{mn}$ to $\$ 978 \mathrm{mn}$ and finance capital assumed a commanding role in the region [World Bank 1983:176]. The accelerated dependence on external sources of financing was accompanied by a massive growth in the external debt over the same period from $\$ 439 \mathrm{mn}$ to over $\$ 4.5$ bn [World Bank 1983:178]. By 1981, US private banks had $\$ 3.3$ bn in loans outstanding to the Central American public and private sectors [Barry et al 1983:9]. 
At the level of the US state, the dictatorships of Central America have been the recipients of a vast programme of bilateral and multilateral aid since the Alliance for Progress. Between 1962 and 1978, Washington and the 'international' banks (i.e. World Bank, IMF, Inter-American Development Bank) provided the ruling classes in the region with over $\$ 900 \mathrm{mn}$ and almost $\$ 1.5 \mathrm{bn}$ in economic assistance respectively [US Agency for International Development 1982:47-8, 51-2, 54, 202-5]. The rise in US government financial aid to the right-wing military and military controlled regimes in El Salvador, Honduras and Guatemala since Reagan took office has been striking, even when compared with the last two years of the Carter presidency when these regimes benefitted economically from a shift in Washington's regional policy. During 1979 and 1980 , Honduras and Guatemala received a combined total of $\$ 109.7 \mathrm{mn}$ in US economic assistance; over the three-year period 1981-83, the figure rose to $\$ 347 \mathrm{mn}$. In the case of El Salvador, the Reagan government channeled economic aid at an even greater rate: $\$ 523 \mathrm{mn}$ between 1981 and 1983 compared with $\$ 60.7 \mathrm{mn}$ in $1979-80$ [Weisman 1983:1,11; Smith 1984:4].

In seeking to mobilise support for its political objectives in Central America within the 'international' banks, the Reagan administration has pursued a twopronged strategy:

- maximum pressure to secure passage of loan requests by 'friendly' governments in El Salvador and Guatemala;

- sustained opposition to all development aid for Nicaragua whose government it defines as hostile to US politico-economic interests in the region.

The second objective has achieved considerable success, especially in the Inter-American Development Bank where the US exercises a veto power over the Bank's 'soft loan window'. Between January 1982 and 1983 , the US representative cast negative. votes on seven loan requests by Nicaragua involving a total of $\$ 84.4$ mn [Latin American Regional Reports 1984:2].

Essentially the process of incorporating new US capital with old has been an additive-accommodative relation. The absence of any rupture between the various forms of capital reflects the complementary role they perform, the interlocking interests they share, and their narrow socio-political bases of support in the region which requires strategic alliances with local repressive elites and dependence on the US state.

\section{United States and Central America: the military dimension}

One of the striking features of long-term US policy toward Central America is the continuity between different administrations. From a regional perspective, it has made little difference over time whether there have been Democrats or Republicans, liberals or conservatives, in the White House. US policy-makers (with brief exceptional interludes) have relied on their military options and alliances with the area's armed forces to maintain Central America within Washington's orbit. This continuity in policy reflects the shared strategic position of both Republicans and Democrats that US domination of the region is an unalterable reality.

Since the 1950s, the United States has played a paramount role in financing, training and equipping the armed forces and police constabularies of Central America. These coercive forces have, in turn, acted as powerful institutional collaborators in the pursuit of US goals for the region. During the Alliance for Progress, Washington's military aid programme grew significantly as part of Kennedy's determination to prevent 'another Cuba' in the hemisphere. In the late 1960s and early 1970s, large-scale US military assistance provided much of the hardware for the brutal counterinsurgency 'pacification' campaign in rural Guatemala carried out by the armed forces. The Somoza National Guard in Nicaragua, a 'creature' of the US from its inception to its demise, received millions of dollars worth of American weapons from the Ford and Carter administrations between 1975 and 1978.

In the contemporary conjuncture there is an additional factor which has reinforced or 'overdetermined' the growing US imperial presence in the region: the need of the Reagan administration to achieve a military victory in order to justify the vast armaments programme that is the core of the new Cold War. El Salvador, in particular, has become the theatre in which Reagan hopes to demonstrate that force, not negotiation, 'works' - thus intertwining regional with global politics. Authorised US military aid increased from $\$ 5.9 \mathrm{mn}$ in $1979-80$ to almost $\$ 200 \mathrm{mn}$ between January 1981 and December 1983 [Weisman 1983:1,11; US Agency for International Development 1982:47]. The other major US military buildup has taken place in Honduras where the Pentagon has created 'a substantial semi-permanent military capability' [Hiatt and Omang 1984:A8] and used the country as a site of large and continuing military manoeuvres since Reagan took office. Complementing Honduras's interlocking military relations with the US is its role as a launching base for the Washington financed and trained counterrevolutionary forces seeking to overthrow the Sandinista government in Nicaragua. 
Under Reagan the basic logic of US policy in Central America has outrun immediate economic interests. The logic of war has replaced economic logic to the degree that Washington now links its global policy to a successful military resolution of the regional conflict. At the same time, the strategic military emphasis, while divorced from immediate economic interests, must be placed within the specific historical context of a larger effort to reconstitute the ideology of imperialism and the imperial state in the post-Vietnam era. Washington views the buildup of military power in Central America as the critical element in recreating economic opportunities on a world scale. El Salvador has been defined as the favoured country in which to reassert US power, to gain a military victory which would not only legitimise the Reagan administration's regional policy but also the whole thrust of its new Cold War definition of politics on a regional and international scale.

\section{US Policy and Capitalist Class Interests in Central America}

Historically, US capitalist interests operating in Central America have worked closely with the US state and its repressive 'client' states. In periods of crisis, particularly during those moments when the imperial state has lost the capacity to impose its will, capitalist interests develop a variety of positions relative to the regime in question - from outright opposition to accommodation. The clearest case in point has been the accommodating style of behaviour displayed by the private banks and the multinationals operating in Nicaragua; a position which contrasts with the confrontationist posture adopted by the Reagan administration.

There remains a widely held belief among the US corporate and banking community with holdings or financial exposure in Nicaragua (unlike US policymakers) that the Sandinista regime is a permanent fixture and that if the private sector is not abolished 'economic realities' will ultimately lead to an economy that is less statist. Many companies, especially those with large fixed investments, have endeavoured to 'ride out' internal changes and adapt to the new operating environment. Delays in obtaining foreign exchange for raw material imports, etc. have been offset by the 'pragmatic' behaviour of Ministry of Economy officials and the absence of any serious conflicts between labour and capital. However, even profitable existing investments have not generated significant new US investments on the grounds that the political-economic direction of the regime has not been sufficiently clarified.

US bankers also tend to characterise Nicaragua's approach to its inherited financial problems as 'pragmatic', despite their refusal to provide virtually any new bank loans since 1979. The bankers' accommodating stance was most strikingly illustrated in the debt renegotiation meetings between Sandinista officials and the country's major financial creditors. In October 1980, an agreement was reached to reschedule $\$ 600 \mathrm{mn}$ (approximately 80 per cent owed to US banks) of Nicaragua's total $\$ 1.6$ bn debt over a two year period. The development of a consensus within the banks' negotiating committee which produced this result grew out of their shifting perceptions of the Sandinista regime's authority and intentions during the course of negotiations. It gradually became clear to these financiers that Managua was determined to negotiate a settlement; that it was prepared to deal pragmatically with the bankers and consider concessions in pursuit of an agreement; and that the Sandinistas were firmly in control of political and state power and, therefore, in a position to make necessary concessions.

The efforts of the Reagan administration to overthrow the Sandinista government continue to be viewed cautiously by many US companies and banks operating in Nicaragua. Moreover, executives of a number of US-based multinationals interviewed in mid-1983 even went so far as to interpret the administration's military and economic pressures as counterproductive to the interests of foreign capital. Some also voiced displeasure over what they felt was another negative consequence of Washington's policy: increased commercial relations between Nicaragua and capitalist, as well as socialist, bloc countries at the expense of US traders [Gilpin 1983:D7].

The two faces of imperialism, business collaboration and opposition and the military confrontationist position, reflect not only different estimates of the durability of the Sandinista regime but also different sets of strategic priorities. For Washington the regional conflict is embedded in a global strategy and thus the ideological and symbolic meaning of 'defeating Marxism' becomes paramount. For the bankers and multinationals the strategic issue is preventing the repudiation of the debt and the disintegration of the private sector.

Thus the historical convergence of a policy between the state and capital is not incompatible with the appearance of divergences in a particular conjucture. Investment capital's flexibility is indicative of the belief that the imperatives of underdevelopment force revolutionaries to come to terms with it. The prudent counter-revolutionary policy adopted by business reflects the desire to support the destabilisation of the regime provided there are good chances that it will succeed. On the other hand, it is opposed to hardline policies if they provide few prospects for success since 
the eventual outcome would be to radicalise the regime. Thus the divergences between capital and the state reflect a pragmatic or opportunist position on the part of capital which, however, may succumb to a state with strong ideological-strategic concerns - a consequence which is apparently unfolding in Nicaragua.

\section{Canada and Central America: the economic dimension}

The Canadian state and capital does not have the long-term deep structural ties with the Central American ruling classes that their US counterparts developed and cultivated. Canada's linkages are primarily commercial, relatively recent and largely independent of client-state patronage. The nature of the Canadian commitment is essential to an understanding of the Canadian government's capacity to disassociate itself from the most heinous regimes or policies in the region. The economic trade, as opposed to the political-military, emphasis in Canada's relations with Central America, explains why it is possible for Ottawa to diverge from Washington's policy when the latter attempts to impose an economic blockade on a regime such as Nicaragua. Similarly, Canada is less likely to diverge from the US when it involves limiting its trade with a human rights violator (e.g. Guatemala) which is allied with the US. Trading with revolutionary states and US clients thus reflects the commercial influences that shape Canadian foreign policy in the region.

While the Canadian investment and financial presence in Central America has grown steadily over the last decade and a half, under the Trudeau government the role of trade assumed even greater importance. Ottawa's 'third option' strategy to break Canada's trade dependence on the United States has been facilitated by the setting up of two state agencies: the Canadian International Development Agency (CIDA) which administers the government's bilateral aid programme for the hemisphere; and an Export Development Corporation (EDC) which provides subsidies and other supports for Canadian traders. Although the largest trade gains during the 1970s were recorded in Latin America and the Commonwealth Caribbean, the value of Canadian exports to Central America still more than quadrupled from $\$ 25.7 \mathrm{mn}$ in 1970 to $\$ 140.3 \mathrm{mn}$ in 1980 [Business Latin America, 5 January 1983; Murray 1981-82:119-20].

The other side of Canadian policy is its accommodation to US policy in the region, reflecting the opposition of Canadian capital to social revolution and the recognition that the US imperial state provides an 'umbrella' under which it can effectively operate. The duality of Canadian policy thus moves between the parameters of US hegemony and Central American revolution - one side threatens displacement, the other threatens expropriation. Canadian capital, as capital of a 'follower nation', seeks to limit intervention without facilitating revolution, carving out political and economic space for itself.

The Trudeau government's bilateral aid programme in Central America and Canada's voting behaviour within the 'international' banks during the late Carter and Reagan administrations mirrored some of the contradictory qualities of official policy statements: instances of collaboration with Washington's objectives were interspaced with decisions that reflect an independent policy position. Honduras, for example, although a centre of US military activity in Central America and a base for counter-revolutionary operations against Nicaragua, has been designated a 'country focus' by CIDA. Bilateral assistance for the three-year period $1980-83$ totalled $\$ 43.7 \mathrm{mn}$ and, according to Canadian officials, this figure could almost double over the next five years [Canadian International Development Agency 1983]. Meanwhile, Ottawa maintains an ongoing economic relationship with the Sandinista regime, extending millions of dollars in lines of credit to Managua, while trying simultaneously to accommodate the twin goals of promoting trade and maintaining aid at a level that would not unduly antagonise Washington.

Between 1980 and 1982, the Canadian executive director in the Inter-American Development Bank (BID) abstained on three loan requests by El Salvador totalling over $\$ 90 \mathrm{mn}$ but also voted with Washington to approve a $\$ 79 \mathrm{mn}$ dam project loan. Similarly, in the International Monetary Fund, Canada supported a $\$ 39 \mathrm{mn}$ Salvadoran loan, ultimately approved under enormous US pressure despite its failure to meet the normal lender requirements of the IMF, only to turn around and oppose a subsequent $\$ 129 \mathrm{mn}$ standby loan to the regime in El Salvador [McDowell 1983:15; Morrell and Biddle 1983:4].

The sharpest area of disagreement between the US and Canada in the 'international' banks revolves around the question of economic assistance to Nicaragua especially in the BID where US policy has been opposed by a majority of the membership, including Canada. One of the more notable clashes concerned a $\$ 2.2 \mathrm{mn}$ Nicaraguan loan disbursal request in June 1983 to complete a road building project. Every member country except the US supported the loan which the American representative subsequently vetoed on 'macroeconomic' grounds. At the June meeting of the board of BID, Canadian executive director Henry Hodder argued that there was no economic basis for rejecting the proposal and 
pointedly noted that the bank staff had found the loan perfectly acceptable [Rossiter 1984:4].

\section{The Canadian Government and Central America: divergence and accommodation with US policy}

Canadian policy toward Central America under the Trudeau government was a contradictory mix of public criticism of US actions and official and practical cooperation, reflecting a determination on Ottawa's part not to allow differences over this issue to provoke a fundamental rupture between the two countries.

The public statements of Canadian policy-makers were often at sharp variance with Washington's policy:

- the origins of the crisis are ascribed to internal economic and social factors rather than Soviet-Cuban subversion;

- a cluster of ideologically diverse regimes is preferred to a region dominated by repressive capitalist regimes;

- political negotiations, not the militarisation of civil society, is viewed from Ottawa as the only realistic solution to the conflict.

Trudeau addressed the issue of US-Canadian differences over Central America at a press conference in April 1983: 'There are major divergences, beginning with the fact that we object to the interference in the internal affairs of other countries by any major power, even if that power is our friend. We certainly said that to the [United] States before ...' [Gray 1983:1]. The following August, in meetings with senior officials responsible for Latin American policy within the Reagan administration, the Canadian Ambassador to the United States, Allan Gotlieb, expressed Ottawa's concern over US military escalation in the region and reiterated his government's preference for a 'political approach' to the Nicaraguan problem [Valpy 1983:6].

However, the Trudeau government's differences with Washington over Central America were conveyed primarily through 'quiet diplomacy', and coexisted with instances of both public and private alignment with Reagan policy. Throughout 1982 and 1983, for instance, Canadian statements critical of the 'escalating military confrontation' in Central America were accompanied by declarations of support for the US military buildup in El Salvador which officials justified by ascribing legitimacy to the existing government and exhibiting concern over guerrilla gains.
In June 1983, Trudeau told the Canadian House of Commons that he saw no reason for the US to end its military activities in the region as long as other external forces were similarly involved [Toronto Globe and Mail, 9 June 1983]. This tacit acknowledgement of Washington's contention that Central America is an arena for the 'testing of wills' between the US and Soviet Union was again demonstrated when he declared before parliament that what the United States does in Latin America is its own business because the Spanish-speaking world is one of its spheres of influence' [Riley 1983:22].

Thus, Canadian policy toward Central America under Trudeau has evolved indepedently of the United States to a limited degree. This independence is reflected in Ottawa's refusal to lend its support to military adventures, in its consistent support of a political solution to the regional crisis, in its more eclectic choice of economic partners (e.g. Guatemala and Nicaragua), and in its refusal to side with Washington in opposing 'international' bank loans to the Sandinista regime. At the same time, there has been a gradual shift towards conceding the primacy of US interest in the region and a parallel growth in official Canadian criticism of the 'authorita rian' tendencies of the Nicaraguan government and the guerrilla movement in El Salvador. This convergence with US policy, shaped by an overriding concern not to let Central America become the occasion for a major rift in bilateral relations, has not, however, had any demonstrable impact on the basic thrust of Reagan policy. Ineffectual support in some areas coexists with ineffectual opposition in others. Although Canada remains critical of the US emphasis on military solutions in Central America, both countries share a common global purpose, and ultimately Canada depends on the 'umbrella' provided by the US 'imperial system' of which they are both a part.

While Canadian policy toward Central America has displayed a relative autonomy from the United States, the Trudeau government's behaviour nonetheless suggests that the capacity or willingness of the Canadians to develop a consequential position differing from that of Washington is sharply limited. The basic constraints on Canadian actions, which account for practical accommodations with White House policy, are several. First and foremost are the bilateral relations between Canada and the US which constitute the prime foreign economic ties for Canada. Second, there is the preponderant dependence of Canadian capital on the US state to counter revolutionary developments in the area. Third are the shared interests and activities of US subsidiaries based in Canada which operate in Central America and US mulinationals. Fourth, there are the joint banking 
efforts and consortia that divide up the loan and interest market in the region.

Within these constraints, however, divergences in the trade sphere persist. Canada has developed an increasingly important stake in overseas trade: it is interested in breaking into new markets independently of the ideological texture of the regime. In Central America, not only do politically tied or client governments closely linked with US corporate interests provide limited opportunities for such expansion, but the political conflicts engendered by overt US military intrusions also conflict with the essentially market oriented policies of the Canadian government. At the same time, these trade policies allow Canadian exporters to displace their American counterparts when, for political reasons, the latter abandon markets. The relatively greater importance of market concerns and non-dependence on 'client' political regimes allows Ottawa to adopt a more liberal and flexible approach within the parameters of its ties with the US. However, as Washington deepens its commitments to a military confrontation, allocating more and more resources and manpower, the likelihood is that Canadian policy will become less directly conflictual with the United States, by hiding behind the commonplace rhetoric of accommodation to Great Power hegemony in the region.

\section{References}

Barry, T. et al., 1983, Dollars and Dictators: $a$ Guide to Central America, Grove Press, New York

Business Latin America, 5 January 1983, 'Canadian policy review suggests greater role in regional affairs', p4

Canadian International Development Agency, 1983, Canadians in the Third World: Statistical Annex, CIDA, Ottawa

Gilpin, K. N., 1983, 'Nicaragua outlook worries executives', New York Times, 15 August 1983, ppD1, D7

Gray, J., 1983, 'Trudeau accuses US of interferences in Central America', Toronto Globe and Mail, 23 April $1983, \mathrm{pl}$
Hiatt, F. and J. Omang, 1984, 'US buildup in Honduras described', Washington Post, 1 February 1984, ppA1, A8

LaFeber, W., 1983, Inevitable Revolutions: The United States in Central America, W. W. Norton, New York

Latin America Regional Reports, 13 January 1984, Mexico and Central America, RM-84-01, p2

McDowell, M., 1983, 'El Salvador aid "squandered" analyst reports', Toronto Globe and Mail, 24 March 1983, $\mathrm{p} 15$

Morrell, J. and W. J. Biddle, 1983, Central America: the Financial War, Center for International Policy, Washington

Murray, D. R., 1981-82, 'The bilateral road: Canada and Latin America in the 1980s', International Journal, no 1, pp 108-31

Riley, S., 1983, 'Canada's uneasy stand on a tricky issue', MacLean's, 8 August 1983, p22

Rossiter, C., 1984, The Financial Hit List, Center for International Policy, Washington

Smith, H., 1984, 'Reagan seeks a fourfold increase in arms aid for Salvador regime', New York Times, 18 February 1984, p4

Toronto Globe and Mail, 9 June 1983, 'US needn't withdraw Latin aid, Trudeau in says', p14

US Agency for International Development, 1982, US Overseas Loans and Grants and Assistance from International Organizations, July 1, 1945-September 30. 1982, USAID, Washington

US Department of Commerce, 1981, Survey of Current Business, no 8, USGPO, Washington, August

-1982, Selected Data on US Direct Investment Abroad, 1950-76, USGPO, Washington

-1983, Survey of Current Business, no 8, USGPO, Washington, August

Valpy, M., 1983, 'In the US ear', Toronto Globe and Mail, 9 August 1983, p6

Weisman, S., 1983, 'Reagan denies aim is bigger presence in Latin countries', New York Times, 27 July 1983, pp 1,11

World Bank, 1983, World Development Report 1983, Oxford University Press, Oxford 